\title{
Genetic Organization and Heterogeneity of the Siberian Cedar Pine (Pinus Sibirica Du Tour) Population in the Western Siberia (Tomsk Region)
}

\author{
Anatoliy M. Danchenko, Matvey A. Danchenko and Alexey G. Myasnikov \\ Department of Forestry and Landscape Construction, Institute of Biology, \\ National Research Tomsk State University, Tomsk, Russia. \\ http://dx.doi.org/10.13005/bbra/2078
}

(Received: 10 April 2016; accepted: 10 June 2016)

\begin{abstract}
Cedar forest is the most complex and dynamic formation of the Siberian Taiga. It clearly demonstrates the processes of natural regeneration dynamics, sustainability, space-time structure and biodiversity of Siberian forests (Drozdov and Grishenkov, 2003). Within its range, Siberian stone pine grows in various environmental conditions, including high mountains and marshland, which led to the formation of various ecotypes, forms, biotypes that has been created by nature for centuries (Nikolaeva and Savchuk, 2013). Much attention is currently being paid to biological and seed productivity of cedar cultures depending on their geographical origin (Bratilova and Kalinin, 2012; Matveeva et al, 2012; Dragavcev, 2008). This study involved research on the growth of the Siberian cedar pine (Pinus sibirica Du Tour) in the process of artificial plantation formation. In order to develop methods for the genetic evaluation of plant structures and search for indicators, patterns of growth for $\mathbf{1 0 0}$ model trees were analyzed in the experimental population.
\end{abstract}

Key words: Western Siberia, Tomsk Region, Siberian cedar pine (Pinus sibirica Du Tour), forest cultures, genetic valuation, model plant.

Selection is one of the recognized ways to improve the productivity of future forests. Analytical selection consists of phenogenetic manifestation of natural and artificial populations, definition of their genetic structure, identification of not only the most valuable species and types of plants, but also the most valuable specimens and quantitative assessment of their features as a basis for the choice of selection system.

The purpose of the research is to evaluate the genetic structure of a model population and to check the solving capabilities of various quantitative methods with their further testing in

\footnotetext{
* To whom all correspondence should be addressed. E-mail: forest@mail.tsu.ru
}

natural forests in different environmental conditions.

In this regard the following objectives were defined:

1. To investigate and develop methods for the genetic evaluation of the structure of model forests;

2. To define the direction and method of selection to realize the program of accelerated effect on the plantations created for various purposes.

With the accumulation of biological, ecological and geographical data of the Siberian cedar pine (Kolesnikov and Smolonogov, 1960; Nekrasova, 1972; Danchenko et al, 2012; Myasnikov and Danchenko, 2012; etc.) the identification of morphological variability on 
various grounds (Iroshnikov, 1972) the interest of researchers in this widespread and very valuable species has increased even further. In their works, the authors use a variety of morphological and physiological features as indicators for finding valuable forms and they implement different methods for their assessment and selection.

In order to substantially increase the volume of the material involved in research, the methods which do not require a change of generations are necessary. In recent years, quick assessments of variation components which do not require a change of generations were developed by an Indian researcher - Shrikhande (1957).

\section{MATERIALSANDMETHODS}

An analysis of references on the analytical selection of the Siberian cedar pine allows us to suggest that phenogenetic features and a genotypic population structure are still not studied enough in Siberia, and in some parts of the environment they are not studied at all. There is no comparative analysis of the estimates of the genotypic structure of the population on various environmental backgrounds.

In view of the above, the authors embarked on research in order to clarify the phenotypic expression of the genotype changes due to the changes of environmental conditions, establishing the applicability of the method of positive selection for the Siberian cedar pine in limited parts of the habitat, identifying the effectiveness of the expected improvement of economically valuable features in a certain selection system, and identification of preliminary assessment opportunities of the properties of maternal trees and their posterities on the basis of methods of early diagnosis, development of evaluation methods for the level of individual resistance of selected plants and family reaction of half-sibs to changing external conditions.

The research involved testing of a methodology for sampling experimental material and the use of different mathematical tools to reveal degrees of genetically conditioned variability of economically important traits using 15-year-old cultures of the Siberian cedar pine as an example.

The experimental research was conducted in the South-West of Western Siberia, in the sub-zone of south taiga of the Tomsk Region.

\section{RESULTSAND DISCUSSION}

Analysis of the results obtained by processing the data using the autocorrelation function and the spectral density of the stationary random function (Jenkins and Watts, 1972) involves the following:

1. Comparison of the plants with the same spatial distribution in order to judge the impact of factors on the structure of a feature's changes;

2. Comparison of the plant response to changes in external factors and the nature of metameric feature variability to estimate relative independence from unregulated varying of environmental conditions.

The data obtained allows us to extend the research on natural cedars to identify the genotypic heterogeneity of their growth and fruiting for subsequent verification of selected individuals of different selection categories and evaluation of the expected improvement.

From Table 1 it can be seen that over a decade of crop growth the evaluation of their variance in height has increased almost 12 times and its components grow in proportion to the total dispersion. The variance between couples of plants and their groups of 4, 8 and 16 is associated with the number of varying environmental conditions. The magnitude of variation of growth of adjacent trees over 10 years remained practically unchanged and amounted to an average of $30 \%$. An integral part of the variance in groups and pairs of plants remained unknown (despite the long period of growth and change in the conditions of growth during the same period), i.e. the size of the plants has significantly changed, but the structure of their populations in space and time is preserved.

The differences between dispersion components of the neighboring trees and other groups, except between pairs of trees, are highly reliable, which shows a significant diversity of forest conditions.

Table 2 shows the trend in growth rates of trees for the period from 15 years on eight sections of the crops. From these materials it can be seen that at intervals 1.3 and 4 there is a 

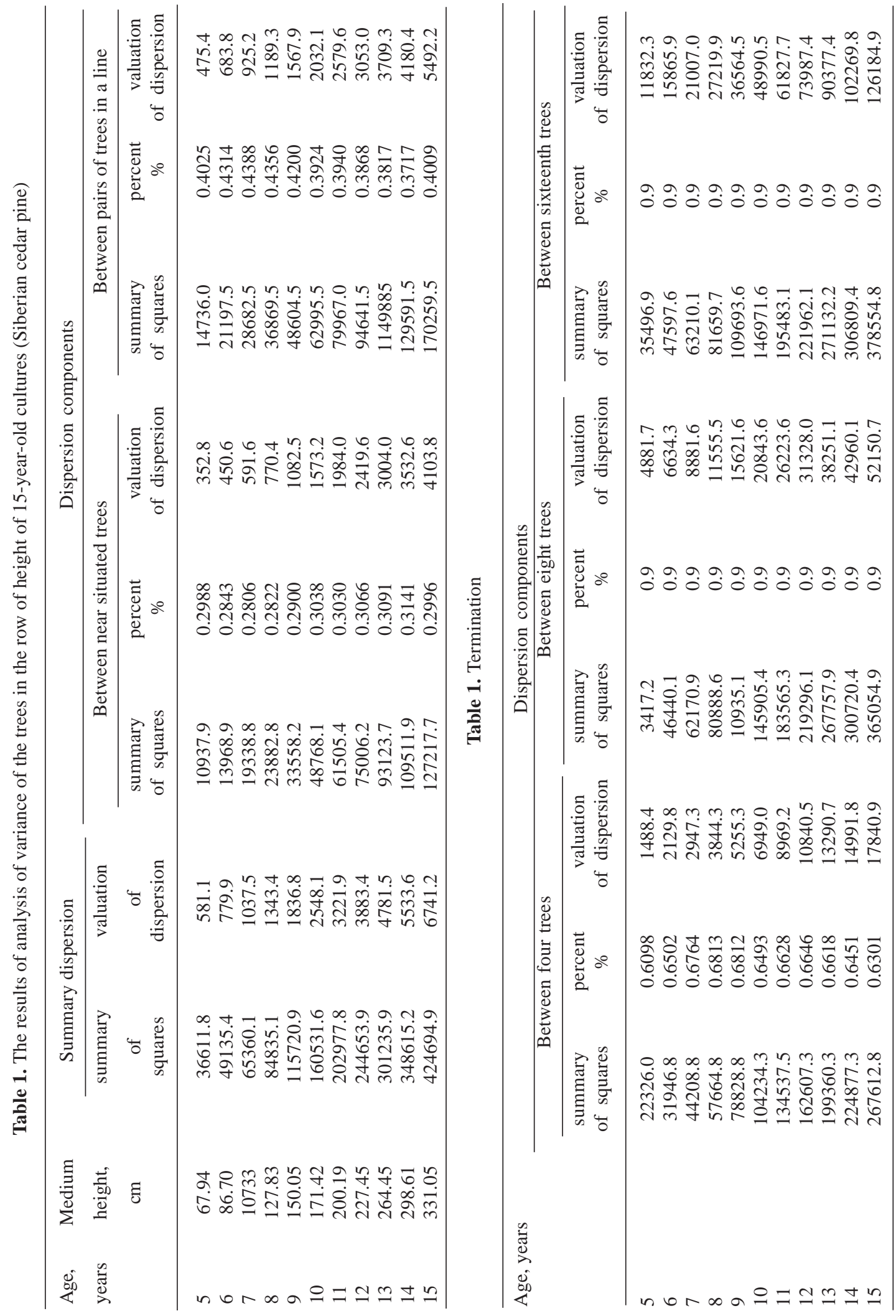
Table 2. Dynamics of indicators of tree growth in height in different parts of a line of forest cultures from 5 to 15 years

\begin{tabular}{|c|c|c|c|c|c|c|c|c|c|c|c|}
\hline \multirow{2}{*}{$\begin{array}{l}\text { No. of section } \\
\text { in line }\end{array}$} & \multicolumn{11}{|c|}{ Height of plants of the age, years } \\
\hline & 5 & 6 & 7 & 8 & 9 & 10 & 11 & 12 & 13 & 14 & 15 \\
\hline \multicolumn{12}{|l|}{ Height, cm } \\
\hline 1 & 51.1 & 64.4 & 80.5 & 97.1 & 114.4 & 131.1 & 155.1 & 180.1 & 213.4 & 248.6 & 280.6 \\
\hline 2 & 69.5 & 89.2 & 109.2 & 128.9 & 148.5 & 169.6 & 199.2 & 227.5 & 263.0 & 296.2 & 330.0 \\
\hline 3 & 56.9 & 74.2 & 92.8 & 109.0 & 129.2 & 145.2 & 172.5 & 200.2 & 235.7 & 269.2 & 296.7 \\
\hline 4 & 62.2 & 79.7 & 100.7 & 118.5 & 136.4 & 156.5 & 184.0 & 208.7 & 242.0 & 273.7 & 296.1 \\
\hline 5 & 81.1 & 101.6 & 122.5 & 145.9 & 170.7 & 191.7 & 223.1 & 250.4 & 292.1 & 326.6 & 368.1 \\
\hline 6 & 68.5 & 88.6 & 110.2 & 133.9 & 157.0 & 181.2 & 212.7 & 243.6 & 281.5 & 314.9 & 349.7 \\
\hline 7 & 80.2 & 10.3 & 129.6 & 154.5 & 183.6 & 210.7 & 244.6 & 273.6 & 317.4 & 353.1 & 394.6 \\
\hline 8 & 73.8 & 92.2 & 113.0 & 134.9 & 160.5 & 185.1 & 216.1 & 235.4 & 271.5 & 308.4 & 340.4 \\
\hline \multicolumn{12}{|c|}{ Order coefficient } \\
\hline 1 & 0.75 & 0.74 & 0.75 & 0.76 & 0.76 & 0.76 & 0.77 & 0.79 & 0.80 & 0.83 & 0.84 \\
\hline 2 & 1.02 & 1.03 & 1.01 & 1.01 & 0.99 & 0.99 & 0.99 & 1.00 & 0.99 & 0.99 & 1.00 \\
\hline 3 & 0.84 & 0.85 & 0.86 & 0.85 & 0.86 & 0.85 & 0.86 & 0.88 & 0.89 & 0.90 & 0.90 \\
\hline 4 & 0.92 & 0.92 & 0.93 & 0.93 & 0.91 & 0.91 & 0.92 & 0.92 & 0.91 & 0.92 & 0.90 \\
\hline 5 & 1.19 & 1.17 & 1.14 & 1.14 & 1.14 & 1.12 & 1.12 & 1.10 & 1.10 & 1.10 & 1.11 \\
\hline 6 & 1.00 & 1.02 & 1.03 & 1.05 & 1.05 & 1.06 & 1.06 & 1.07 & 1.06 & 1.05 & 1.06 \\
\hline 7 & 1.18 & 1.19 & 1.20 & 1.21 & 1.22 & 1.23 & 1.22 & 1.21 & 1.20 & 1.18 & 1.19 \\
\hline 8 & 1.10 & 1.06 & 1.05 & 1.05 & 1.07 & 1.08 & 1.08 & 1.03 & 1.03 & 1.03 & 1.03 \\
\hline
\end{tabular}

significant lag in growth of trees compared with other parts of the series. At the age of 15, the difference in the average height of the areas with the best growth reaches $0.5-1.5 \mathrm{~m}$. Rank coefficients of tree height in different parts of the series remain unchanged with age, as evidenced by the value of the correlation ratio $(=0.96)$. This suggests that at a different growth rate the trees grow throughout the series according to the same principle.

Calculation of the heritability coefficient of tree height using Shrikhande's method revealed a remarkable genotypic diversity $\left(\mathbf{I}^{2}=0.78\right)$ in the Siberian cedar pine, showing higher growth rates at the age of 15 .

Consequently, selection may lead to a noticeable effect. However, this method requires testing with more representative samples prior to widespread use in practice.

\section{CONCLUSION}

The research results show that analysis of the structure of the phenotypic variability of traits of individuals in populations is an effective means of gaining knowledge of the processes of ontogenetic and biocenotic levels of plant life organization and is a prerequisite for the identification and development of the resources on the genetic variability of plants.

Analysis of the structure of measurable trait variability in populations leads to the formulation of problems of morphological measurements and to the justification of quantitative methods to solve them.

Research aimed at the development of measurement problems, especially from the position of its analytical direction - phonetics - is a promising area in botany and plant genetics.

\section{REFERENCES}

1. Bratilova N.P., Kalinin A.V.: Ocenka bioproduktivnosti plantacionnyh kul'tur kedrovyh sosen v zelenoj zone Krasnojarska. Krasnojarsk: SibGTU, 2012; 132 p.

2. Danchenko A.M., Myasnikov A.G., Koshkina A.V., Danchenko M.A. Zonalnyie osobennosti formirovaniya lesnyih fitotsenozov i lesohozyaystvennoe rayonirovanie Zapadnoy Sibiri. Fundamentalnyie issledovaniya, 2012; 11 (chast 6): 1324-1328.

3. Dragavcev V.A. Osnovy budushhih naukoemkih selekcionnyh tehnologij dlja geneticheskogo 
uluchshenija poligennyh jekonomicheski vazhnyh svojstv rastenij. Agrarnaja Rossija, 2008; 4: 2-10.

4. Drozdov I.I., Grishenkov A.A. Sosny kedrovye - orehonosy. Lesohozjajstvennaja informacija, 2003; 5: 6-9.

5. Iroshnikov À.I. Zakonomernosti vnutrividovoy izmenchivosti listvennitsi sibirskoy i kedra sibirskogo. Mezhdunarodniy simposium po selektsii, genetike i lesnomu semenovodstvu hvoinyh, 1972; 26-37.

6. Jenkins G., Watts D.: Spectralniy analiz i ego prilozheniya. Moskva: Mir, 1972; 287 p.

7. Kolesnikov B.P., Smolongov E.P. Nekotoriye zakonomernosti vozrastnoy i vosstanovitelnoy dinamiki kedrov lesov Zauralskogo Priobya. Problemy kedra, 1960; 6: 21-33.

8. Matveeva R.N., Butorova O.F., Pastuhova A.M.: Otbor kedrovyh sosen po urozhajnosti na plantacii «Meteostancija» (zelenaja zona g. Krasnojarska). Krasnojarsk: SibGTU, 2012; 155 p.
9. Myasnikov A.G., Danchenko M.A. Analiz dinamiki lesnogo fonda Asino-Tomskogo lesoekonomicheskogo rayona Tomskoy oblasti. Sovremennyie problemyi nauki i obrazovaniya, 2012; 6: 2-11.

10. Myasnikov A.G., Danchenko A.M. Izuchenie dinamiki lesnogo fonda Obsko-Tomskogo lesoekonomicheskogo rayona Tomskoy oblasti. Nauchnoe obozrenie, 2012; 6: 46-51.

11. Nekrasova Ò.P.: Biologicheskiye osnovy semenosheniya kedra sibirskogo. Novosibirsk: Nauka, 1972; 273 p.

12. Nikolaeva S.A., Savchuk D.A. Morfologicheskie formy kedra sibirskogo (Pinus sibirica Du Tour) v vysokogornyh lesah Severo-Chujskogo hrebta: I. Morfologicheskij aspekt. Vestnik Tomskogo gosudarstvennogo universiteta. Biologija, 2013; 2 (22): 101-114.

13. Shrikhande V.J. Some considerations in designing experiments on coconut trees. J. Indian Soc. Agric. Statistics, 1957; 9: 82-91. 